\title{
Parental expectations of the Swedish municipal school of arts
}

\author{
Jonathan Lilliedahl and Eva Georgii-Hemming \\ Örebro University, School of Music, Theatre and Art, SE-701 82 Örebro, Sweden \\ jonathan.lilliedahl@oru.se
}

This article draws on a study designed to analyse parental expectations of the Swedish municipal school of arts (hereafter MSA) (in Swedish: kommunal musik- och kulturskola). The study is based on in-depth interviews conducted and informed by grounded theory. Although parental expectations are scarcely uniform, the study reveals a hope that the whole child will be nurtured, both musically and socially. It also transpires that parental expectations vary according to the activities offered by the particular school. The MSAs are administered and financed by the local authorities, and parents therefore expect them to be distinguished not only by their educational ambitions and the range of cultural choices available, but also by their democratic norms and values.

\section{Introduction}

This article draws on a study designed to analyse parental expectations of the Swedish municipal school of arts (hereafter MSA) (in Swedish: kommunal musik- och kulturskola). The primary aim of the study was to identify the parents' expectations, and to evaluate these in the light of the schools' stated mission. From an international perspective the MSA is a quite unique school form and its prerequisites are essential for the research reported here. Therefore, the main contour of the setting is provided in this introductory paragraph, followed by a historical overview of the origins and growth of the Swedish municipal school of arts.

Sweden is divided into 290 local authorities, the geographical areas and administrative units of local self-government. Between 2004 and 2006, all but eight of these offered an optional musical education in the form of an MSA.

Children who attend an MSA receive instrumental and ensemble teaching over and above the ordinary music teaching available in school. However, since the 1990s increasing numbers of schools of music have been transformed, the aim being to integrate a wider range of aesthetic subjects into their curricula.

The local authorities are the bodies responsible for both the combined primary and secondary schools (grundskola) and the senior schools (gymnasium) in their districts, as well as for the MSA. The difference is that the obligatory school system is regulated by the state, while attendance at an MSA is voluntary. The council is under no obligation to establish an MSA, and the children are not obliged to take part in its activities. On the other hand, it is not unknown for existing MSAs to collaborate with compulsory schools, either in shared cultural projects, or by arranging instrumental lessons at the premises of the primary-secondary schools. 
Torgil Persson (2001) describes MSAs as '... voluntary, organised music teaching wholly or partly financed by council taxes at the local level' (p. 4). In recent years, $81.2 \%$ of the budget has been financed by council taxes, while the shortfall is made up by income from contract teaching and fees. In 2006, term fees varied from zero to 1,600 SEK (Sveriges Musik- och Kulturskoleråd, 2006). In the same year, some 380,000 pupils participated in MSA activities, of which about half took subject courses (individual instrumental or vocal tuition) and about half took other courses (including projects run in conjunction with primary-secondary schools) (Sveriges Musik- och Kulturskoleråd, 2006). Against this, the number of pupils attending primary-secondary school in the same period came to about 995,000 (Skolverket, 2006). Persson (2001) points out that instead of the MSA in the singular, it might be more appropriate to speak of them as plural. The reason for this lies in the organisations' historical emergence and growth (see below).

Municipal schools of music were first founded in Sweden between the 1920s and 1940s. The initiative was taken not by parents as a group, but rather by political and cultural interests in collaboration with the majority of the powerful popular movements (see below). Today, the MSAs are confronted by a late-modern reality, in which modern ideas of society coalesce with a post-modern drift. Collectivism is pitted against individualism, public against private. The universalism of value conservatism is set against post-modern destabilisation of moral and aesthetic values (Lyotard, 1984; Liedman, 1997; Reimer, 2003; Woodford, 2005). This, thus, is the setting in which parents' private expectations are weighed against public benefit and the general concerns of the local authorities. For the parents' part, an active choice is required, in which financial and practical support is a proviso for their child's participation. Conversely, all parties involved face the puzzle of a tax-funded education provided by the local authority, and nominally open to all, in which not everyone interested can obtain a place. Given the current premium that public institutions place on the idea of the consumer, it becomes relevant to study parental expectations of the Swedish MSAs. The study is limited from the child's perspective; it is the relationship between parents and the school that is under consideration here.

\section{The Municipal School of Arts: origins and growth}

\section{Sweden between the wars}

Pinpointing an exact year for the advent of municipal schools of music in Sweden is impossible. Their founding was not preceded by a parliamentary decision of any kind; it rather reflected local reactions to a national mood. The Swedish 1920s, which as it transpired were to be an inter-war period, were at the time felt to be a buoyant post-war period, ripe with opportunity and set on reinvigorating the modern project that had been launched earlier. Ideas such as democratisation, industrialisation and the rise of technology, urbanisation, secularisation, and the end of class society were the stuff of modern Sweden. Now finally there were the economic resources available to realise a dream of a modern, urban individual prospering in folkhemmet, the Swedish welfare state (Fornäs, 2004).

The emergence of this modern project was matched by calls for a broad-based, universal education that would turn out up-standing members of society, instilled with a strong cultural capital. The interest in universal education shown by both Sweden's popular movements and politicians turned primarily on education, culture and social work. 
When the Social Democrats came to power at the start of the 1920s, there was little knock-on effect on economic and cultural power. It was in this decade that new media, with their unfamiliar, strongly afro-American music, arrived from the USA. Compared to safe, Swedish traditional music, the new popular music - jazz - was felt to be abnormal; threatening and attractive in equal measure (Fornäs, 2004). Despite this, or possibly thanks to it, the cultural values of bourgeois society were to remain firmly entrenched. The dominant opinion that there was an objective cultural heritage that was worth preserving, and that this heritage was of importance to everyone, was unchanged (Edström, 1996). At the same time, people entertained a dream of democratisation, that would leave classical music not an exclusive preserve, but accessible to all, the working classes included. The period was characterised by 'value objectivism', where as a matter of course western classical music and musical notation constituted the basis for teaching (Ruud, 1996; Cook, 1998). The classical tradition was seen as autonomous and authentic, but also as educationally promising (Hamm, 1995); in terms of a universal education, it was thought that it had improving qualities that surmounted context and social class (Stenbäck \& Bouij, 2006). The idea of a universal education was thus a corner-stone of local authority-financed schools of music that were designed to offer affordable instrument tuition, open to all. The schools of music also built on local orchestral traditions and their need for recruits, and the suggestion that the schools would act as nurseries of local talent was one element in securing their future.

The musical ideas and aesthetic norms embodied by the schools of music derived from Western classical music, but in practice the schools became more unaffectedly popularist with time. In the interwar period and for a time following, the general public's music was characterised by what can be called the light classics, an aesthetic compromise between the educated middle class and popular culture. When the schools of music opened their doors, they adopted many of the features of this tradition. The philosophies of Classicism and Romanticism were tailored aesthetically and educationally to be both attractive to young amateur musicians and to be playable (Edström, 1996).

Thus, in the event, the missions of the schools of music were twofold. By supplying children with a meaningful leisure activity one was social salvation. At the same time the schools of music was seen as the safeguarding of aesthetic values. Passing on musical craftsmanship, musical appreciation and 'good' music should preserve these. In other words, educational needs were articulated neither by parents nor children, but by politicians, institutions and the cultural establishment.

\section{Post-war expansion}

In 1950, there were schools of music in some 50 cities and towns, and while over the ensuing decade the pace of the local authorities' initiative grew, the explosive expansion took place in the economically 'good' years of the 1960s and early 1970s. Thanks to their proliferation, the municipal schools of music became the universal form for instrumental lessons (Stålhammar, 1995). The schools' informal mission was not only to lay the basis for amateur music on a local level, but also to cater for the growth of the professional sector (Svenska kommunförbundet, 1984).

In the 1960s, the format of the municipal school of music was formalised as a nationally accredited school type, although local purposes and initiatives ensured that variations in 
local authority ambitions and structures survived. For this reason, the Swedish Association of Local Authorities (Svenska kommunförbundet, 1976, 1984) was elected to compile a set of publications that would create a common platform on a national footing. These publications confirmed the institutions' status as schools, not least through their relationship with the compulsory school. The importance of parental participation was also underlined, but in the shape of practical help rather than any dialogue over the form the teaching should take.

The late-modern $1990 \mathrm{~s}$

In the course of the 1990s, the didactic reference points altered for the municipal schools of music. Post-modern ideas left their mark on their operations, and contributed to a teaching style more focused on the individual, where the pupil's interests were accorded a greater priority than before. Individual development became a central aim, and the pupils' own musical Lebenswelt played a greater role in determining repertoire.

At the start of the 1990s, in many regions, it became necessary to prioritise, when a weak economy dictated a reappraisal of municipal services. It was in this period that the existence of the schools of music was called into question. In several cases, campaigning parents were to be the salvation of schools of music. By the 1990s, many of the parents had themselves attended schools of music in their childhood, and their positive experiences shaped their commitment to the schools' survival.

External threats and a need to demonstrate the value of voluntary instrumental lessons meant that the schools' activities were increasingly legitimised by non-musical objectives. By pointing to such additional benefits as the potential for developing alternative skills and increased social competence, the position of music teaching was reinforced (Graneheim, 1994; Stenbäck \& Bouij, 2006). One route out of the crisis was for schools of music to restructure as schools of arts (kulturskola), and to incorporate other modes of aesthetic expression, so expanding their way out of the crisis (Graneheim, 1994; Stenbäck \& Bouij, 2006).

The crisis of the MSAs was also triggered by reduced demand. This hit traditional orchestral instruments in particular, to the advantage of standard popular-music instruments (Sveriges Musik- och Kulturskoleråd, 2002). This development might well have been viewed as a threat to tradition and musical diversity, yet it made sense in strictly business terms, given that pupils came increasingly to be viewed as customers.

Thus the course of the history of the MSAs in the 20th century can be described as an arc from the early focus on the collective to the current primacy of the individual. The key terms are now education, skill and experience.

\section{Methodology}

\section{Data collection}

The empirical study builds on in-depth interviews with 12 parents whose children attend MSAs. In order to understand the problem from the interviewees' own point of view, an interview technique was adopted that has been dubbed 'half-structured Lebenswelt interviews' (Kvale, 1997). 
The general approach is based on the joint work of Glaser and Strauss (1967) who together formulated Grounded Theory. This approach places particular emphasis on qualitative research as providing an opportunity to attain a substantive level, and with the use of inductive data to generate a contextual theory. In adopting this approach, qualitative interviews are a suitable method for data collection (Strauss, 1987).

In the interviews, interview guidelines were used that were constructed around one principal question: 'What expectations did you have of your local MSA?' From this, a chart was compiled of possible questions and directions the interview might take (Kvale, 1997). In this manner, the interviews all started from the same point, but at the same time were open to other associations being drawn, unlike an interview constructed around prepared questions set out in a hierarchical or predetermined chronological order.

Since Lebenswelt interviews were used, the length of the interviews varied. Personal interviews were complemented with telephone interviews. All interviews were recorded, and were later transcribed verbatim (including laughter, coughs and so on).

The choice of analytical approach was grounded theory, which in turn influenced the process of interviewee selection. The success of grounded theory demands representative informants who can sample the whole population (Danermark et al., 2003). Even if all parents with children at an MSA are possible informants (Glaser \& Strauss, 1967), a purposive sampling and a targeted selection was necessary. The aim was to view the issues from different perspectives in order to reach a broader understanding (Stålhammar, 1999). The selection was based on the following parameters: (1) instrument popularity; (2) the number of children the parents had at the school; (3) the number of years that the parents had had contact with the school; and (4) the children's participation in ensembles, if any. The net was then cast wider than large cities with high average incomes and right-wing dominated councils to include older, blue-collar communities with low average incomes and socialdemocratic councils. All these parameters were then used to sift through potential interviewees, who represented different views on the MSAs, and had different socio-economic, geographic, and educational backgrounds. This selection process produced a short-list, of whom the first 12 to accept the invitation to participate were chosen to be informants.

\section{Analytical method}

The analysis was carried out by a stepped codification of the empirical data. In the process of codification and abstraction, a series of categories and terms emerges, which in turn constitute a local, or substantial, theory (Glaser, 1978). In the final analytical stage, a more formal, generalised theory is reached (Glaser \& Strauss, 1967; Stålhammar, 1999). The theory is generated using the inductively substantive, but in order to place all that is specific and contextual in an overarching context, empiricism is tested during the interpretative phase against both structural and deductive thinking (Strauss \& Corbin, 1990). The operation of theory, where 'all is data' (Glaser, 2001), demands a degree of theoretical sensitivity (Glaser, 1978).

In the present study, an initial open codification broke down the empirical data into smaller sections. By examining the material and comparing the evidence, certain similarities and differences emerged that resolved into a series of terms and categories (Strauss \& Corbin, 1990; Glaser, 1992; Stålhammar, 1999). In the second phase, axial codification, the various categories were compared. At this level, the connections and relationships 
between the categories were traced (Strauss \& Corbin, 1990; Glaser, 1992; Stålhammar, 1999). The final stage was a selective codification, with a level of abstraction that was that much greater. Here the focus was on the core categories - those which occur frequently in the material, and which can readily be related to the others - that were to contribute to the general theory (Strauss, 1987). This final codification was therefore intended to reach a generalised level (Glaser \& Strauss, 1967; Stålhammar, 1999). Codification continued until theory saturation was reached, the point at which further codification adds no further information to the categories (Strauss, 1987). The reason for the selective codification was to elevate substantial opinions to the level of formal theory, where the 12 parents can be taken to represent the expectations and ideas in a reflection of reality that is empirically sound. However, it is not possible to offer results that can be said to be a quantitatively valid picture of the entire population.

\section{Results}

Thanks to the codification process of the source material, the study has generated a wellgrounded theory of parental expectations of MSAs (see Fig. 1).

Common to all parental expectations of such schools and their operations is a central concern with the child's development. Yet the underlying reasons for this development, and what it might mean for parents, varies.

This section presents the general theory; one that reflects the categories of parental expectation to be found in the source material, with the stress points of individual versus group perspectives, and intra-musical versus extra-musical. How these issues relate to the growth, mission and work of the MSAs is then analysed.

At the general level, the study shows that parents, both individually and as a group, have a series of expectations of a musical education. Goals are clearly related to the individual child, but reflect both social and musical development. The study also shows that parents modify their expectations according to the activities that are on offer. As long as no problems of a practical, financial or administrative nature arise, most parents are satisfied.

Amongst those parents who have several children at an MSA, expectations vary from one child to the next. The 'original' expectations and rationalisations were thus evidently contextual and adopted to the individual child.

Where parents had their own experience with which to compare, two key changes were mentioned as being particularly encouraging. One is the current opportunity for ensemble playing. Many parents see individual instrumental lessons as the raison d'être of the schools - just as it was when they attended - yet at the same time, they place great value in the fact that ensemble playing has become an almost self-evident corollary. The other is the reorganisation of the MSAs, a development that is regarded as offering greater opportunities for a broader view of culture.

\section{Individual and intra-musical needs}

At this stress point (compare Fig. 1) one finds the objectives that relate to musical proficiency. Parents expect their children to receive a basic, but qualified, musical education, and MSAs are seen as educational institutions. Interviewee $\mathrm{K}$ noted that this is a qualified music 


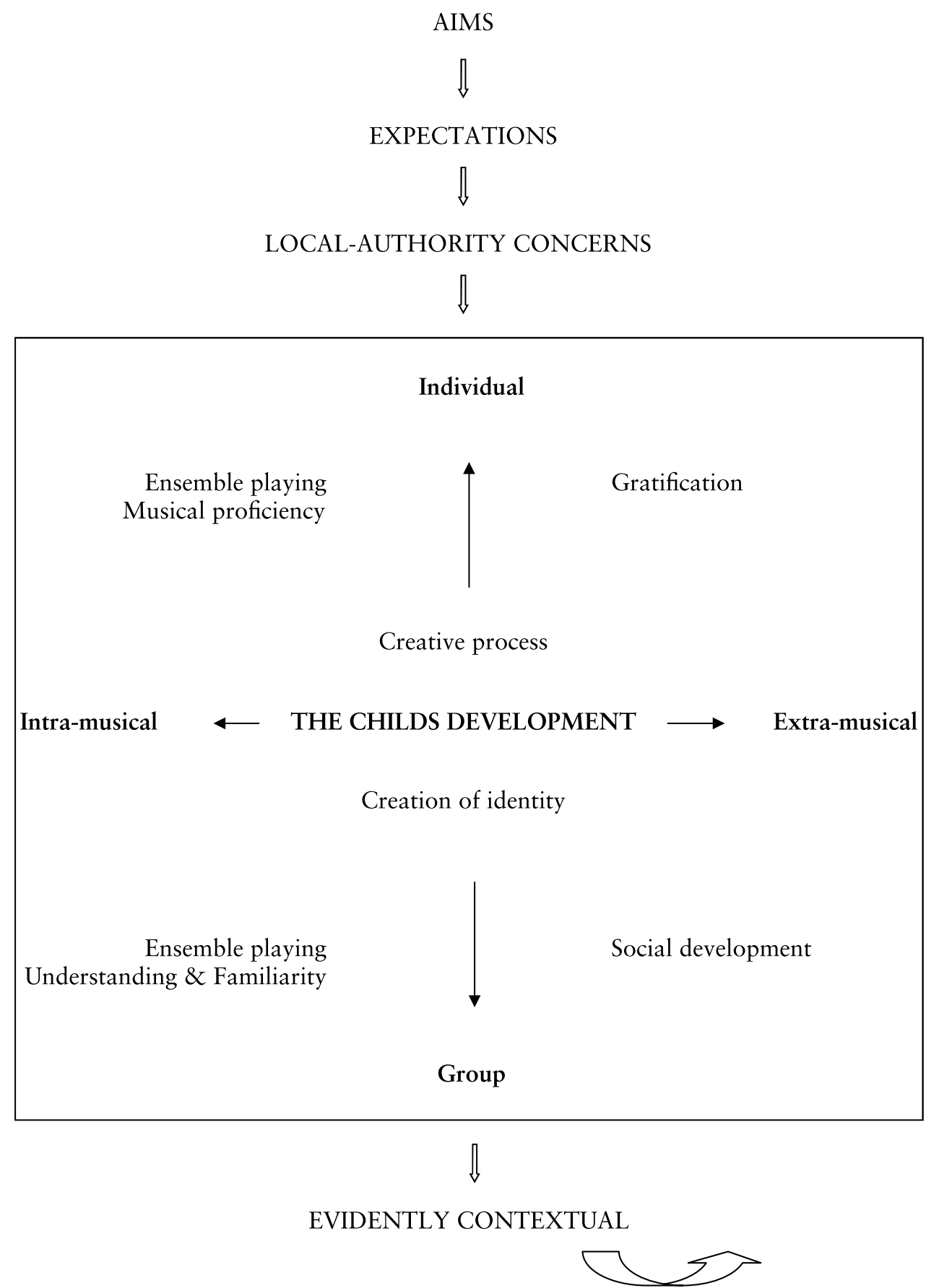

Fig. 1 Theory of parental expectations

\section{CAMBRIDGE JOURNALS}


education, and not just a sort of hobby, but it's an education with an academically trained teacher'. The children are expected to learn an instrument, and even if parents think that the scope for learning by ear could be greater, it is still true that an ability to read traditional staff notation is thought more important. The idea of individual tuition belongs here, a tradition in which master and pupil meet in a knowledge transfer that adheres to deductive principles, and where continuous practice is expected of the child. That said, the tuition is understood as being tailored to the individual, and it is expected that the child's own interests will be taken into consideration.

Even if parents place an emphasis on proficiency, it does not mean that they necessarily think the child will go on to work professionally in music. Several look upon its aesthetic function as meeting a vital human need. Music 'reaches the soul' in a way that sport does not, and so all children should have the opportunity to try; they might discover that music can be a source of joy throughout their lives.

At this stress point, because the ideal is a cumulative, holistic approach, parental expectations can take on an extra-musical slant. MSAs are expected to focus on the creative process and the individual, and primarily to be a forum where children are allowed express themselves through music; for this to be possible, the parents believe that proficiency in an instrument is an essential prerequisite. However, the same parents believe the most important thing is to stimulate and develop the child's musical interest and artistic creativity. In their lessons, the pupils themselves should be allowed to discover and create, and the teacher's role is to enable this. To be encouraged and to have the opportunity to try different means of artistic expression are essential.

\section{Individual and extra-musical needs}

The stress point where individual and extra-musical goals intersect reflects the individual's sense of gratification and what we call 'entertainment' and 'experience'. Unlike the previous category, here the parents disregard knowledge and proficiency in favour of the idea that music is an activity that should always be experienced as fun. Its rationale is not that children are engaged in music per se, but rather that they find it an enjoyable recreation. The form the teaching takes is thought secondary to the teacher's ability to encourage, praise and adapt to the child's needs.

As well as its ability to improve quality of life, the value of music lies in its improving nature. Several parents remarked on research that had convinced them that music is generally beneficial; in improving motor function and physique, and in promoting learning in a wider sense.

It is at this stress point that the creation of a child's identity is a source of much reflection. Music as a mode of expression is 'a way of behaving', which makes identity-creation a central notion. The duality derives from the expectation that children will find their identity in music and yet also through music. Creative activity is in some senses unique, and is potentially an undertaking in which people can 'find themselves'. At the same time, it is thought crucial that children should be given the opportunity to find 'their thing', which could just as well be something other than music.

From all this it emerges that children are not expected to take music too seriously, and that parents have relatively low expectations, both of their children's practice and of the MSAs in general. Interviewee M said that in her opinion 'my expectations are probably not 
much more than the children should think it's fun and that everything works, then it's all great, I reckon'. Parents try to 'pep talk' their children into practicing, but in the long run it is the child who chooses whether to continue or quit.

\section{Group and intra-musical needs}

When a group perspective is combined with intra-musical goals, we can identify expectations of children's familiarity with - and understanding of - the skills to which they have been exposed. This category runs in a clear parallel to the first, and many parents speak of ensemble lessons as an important complement to individual tuition. Interviewee N's comment provides a good example: 'I think it's a good thing that they start playing in ensembles early on. Then they see the point of playing an instrument quicker than ploughing on alone, which is a really big difference from what it used to be.'

For most parents, it is important that their child has a chance to join in both concerts and ensemble playing. The key expectation here is that the school will offer ensembles at different levels so that all pupils find a place and the necessary motivation.

Musically, parents think the worth of ensemble playing is that children understand more readily the purpose behind their individual tuition. In an ensemble, children can have a musical 'kick' from hearing themselves as part of a greater musical whole. There is also a strong educative element, since ensemble playing demands both discipline and insight, musically and socially. In an ensemble, children can experience their human significance as an individual in a collective society.

\section{Group and extra-musical needs}

In this category we find chiefly the social returns that can be obtained through group tuition. Parental expectations here are that MSAs will foster the child's social competence. Group tuition is thought of as a means to extra-musical ends.

Music is seen as providing a practicable alternative to 'kicking about the streets', and the schools' activities provide a secure environment in which the child can make friends, with music as a common denominator. Be it a string orchestra or a brass band, a rock band or a salsa group, there is a strong sense of community, where everyone looks after each other; it encourages a sense of assurance, self-esteem, and inspiration that can be carried over into other aspects of life. Some parents think that music and sport fulfil the same function in this respect. The difference is that MSAs do not demand as great a commitment from the parents as do non-profit sports clubs.

\section{MSAs as local-authority concerns}

Fundamental to the parents' expectations is that their local MSA is one of their local authority's services. The empirical material demonstrates a clear agreement on what the institution symbolises (although, turning to those parents who have generally low expectations of their particular child's music tuition, we find a small divergence since some of them do not mention it at all). That said, generally the parents' own experiences as local residents frame such expectations as already exist, and have a bearing on such as arise in the course of contact with the school. 
Parents expect the MSAs to be constituted on democratic principles. This means that the school should be open to all, including socially and ethnically weak groups; the fees should be affordable; and the school should be accessible, geographically, physically and ideologically. Interviewee M:

In one way, I think probably one expects it [MSA's ethos] given that it is council-run, so it stands for a certain standard or it's all to do with the council being responsible. In a way it's all part and parcel, in the end, of all democratic issues, that they should be equal, they should be fair [...].

There is a general belief that private alternatives would probably be too expensive. Additionally, several parents expected their local MSA and cultural institutions to collaborate when it comes to curriculum.

The parents' confidence in the schools' work is considerable. The term municipal school of arts is a guarantee that the teaching represents the best in educational and musical quality. Here the parents' assumption is that the staff are 'appropriately educated people who can mediate the right skills', something that is not seen as inevitable when it comes to private alternatives. The 'right' skills are important; they are the ones thought intrinsic to the schools' success in offering a broad choice, and catering for as many interests as possible. It also means that streaming by ability is rendered impossible, something that the parents appreciate. The civic ethos embodied by the 'municipal' is also assumed to create equivalence between local authorities, while larger variations are supposedly typical of the private market. The teaching in MSAs is not regulated in a national curriculum. For this reason, the interviewees were asked whether there should to be any shared requirements or values for MSAs in terms of syllabus or objectives. The answers demonstrate that the parents expect this to be the case when the local authority is in charge. Above all, they expect MSAs to embody norms and values instituted on democratic principles. For some parents, it is irrelevant whether the school is in private or local authority hands; it is the teachers' commitment that is crucial. These parents speak of specific teachers - the right person at the right time - who have displayed boundless enthusiasm and a sense of vocation throughout the child's childhood and adolescence.

Parents also emphasise the local authorities' social responsibility, and that in this respect MSAs can reasonably be expected to work actively with groups who are in need of particular support, such as ethnic minorities or socially disadvantaged families.

\section{Analysis}

The child's needs

In many respects, the parents' aims in sending their children to an MSA tally with their views on their particular child's needs and overall development. In Interviewee M's words, 'the expectations I have are bound up with what my children expect'. This poses several major challenges both to the schools as organisations and to individual teachers. First, parental expectation generates infinite variations; variations that must be identified, understood and met. Second, the child's needs are not always the same as the child's interests. 
Previous music education studies have shown that pupils' success depends on parental commitment. A fruitful - and constant - dialogue with parents and children is the key to teaching that is tailored to the individual (Calissendorff, 2005). The wishes formulated in such exchanges can easily range across ethnic and musical expression, genre, teaching method, and rate of progress; complying with them places great demands on teachers' musical, educational, and social readiness to act. All this before one reaches the question of what role the music teacher can and should play in such a dialogue (Georgii-Hemming, 2005).

Life as an 'exercise in enjoyment' is another theme discussed in the literature. In a society that is seen as undergoing rapid change, people seek immediate gratification, while longer-term rewards have become less attractive (Edström, 2002). The trend is for children to be increasingly disinclined to learn an instrument in order to reach long-term goals (Stenbäck \& Bouij, 2006). It also means that teachers' needs must be more laissez-faire, while the concern with amusement leads to an increased focus on positive experiences (Edström, 2002).

When not subscribing to the authoritarianism of the western musical and pedagogical canons, teachers may have gone too far in the other direction, giving children and their parents what they want or resorting to spectacle and bombast when they ought to be helping them to intelligently explore the musical world while exercising self-restraint (Woodford 2005: 26).

Even were we to argue that many different dimensions of each pupil's experiences and interests ought to be involved - that music lessons ought to be experienced as meaningful the question remains whether this can be achieved if the agenda is set wholly by the pupils' or parents' expectations (Georgii-Hemming, 2006).

Children and adolescents today have a wealth of musical experience. Studies show not only that their experiences are strongly tied to emotional and physical contexts, but also that they are of great significance in identity processes (Ruud, 2006; Stålhammar, 2004). The pupils' own Lebenswelt and musical world is thus a good starting point for giving relevance to any teaching, but at the same time it creates difficulties in motivating longterm application. It is easy for teaching to become experience-controlled, while musical didactic criteria - such as progression - are overlooked (Hanken \& Johansen, 1998; Nielsen, 1998). By always starting from pupils' everyday experiences, teaching runs the risk of only reproducing an already familiar Lebenswelt, and loses the opportunity of broadening it. To make serious provision for a child's development, it is essential for the teacher to help the pupil step beyond the known to face the 'unknown' (Sernhede, 2006). This does not mean that pupils must be inculcated into a 'grand' culture. The preferred education is one not in the first instance characterised by the appropriation of a canon of masterpieces, but rather by the enquiring mind that repeatedly strays from its familiar path, and, by assimilating the previously unknown, widens its horizons of understanding (Gustavsson, 1996; Gadamer, 1997). By encountering the unfamiliar, pupils are given the opportunity to orient themselves in the world in which they live, and to enrich their Lebenswelt; a Lebenswelt shaped by experience of musically and ethnically diverse cultures (Jorgensen, 2006). It follows that their ability to meet and understand not only other people with differing experiences, but also the codes communicated by the media, can only increase (see Hall, 2007). 
The municipal school of arts: what are the broad implications?

Swedish MSAs are heterogeneous (Persson, 2001). Although attempts have been made to create a national, shared platform, the schools are without a doubt locally fashioned, and are strongly influenced by their local cultural traditions. Amongst the parents interviewed in this study, many had implicit expectations that were adapted to specific schools' traditions, structure and ideology. Just as earlier studies have shown that teachers are socialised into a local culture and school code, where 'odd' is transformed into 'normal', we see here parents conditioned to accept a certain style of teaching (Jorgensen, 1997; Stålhammar, 1999).

That the schools come under local authority control creates a series of expectations: democratic organisation; a choice not dictated by the market; and a broad range of activities with several different means of aesthetic expression. The study shows that MSAs are in every way expected to be 'a school for everyone'.

The evolution of the MSAs tracks the evolution of society at large, from modernist collectivism to late-modern individualism (Liedman, 1997): from a focus on the subject to an increased focus on the pupils; from music alone to a wider aesthetic choice; and with a holistic approach to the individual as an intellectual, emotional and physical being (Varkøy, 1996; Nielsen, 1998). Post-modernism has been criticised for clearing away everything except absolute relativism, but it can also be welcomed for making possible a multiplicity of interpretations and possibilities (Biesta, 1999). An institution that was founded in order to foster the next generation of musicians and to pass on musical craftsmanship, all while 'saving' young people from destructive amusements, is viewed by present-day parents as an institution dedicated to both education and entertainment.

In music education or the philosophy of music, this is sometimes described as the 'ends or means' debate; whether music is an end in itself, or a means to an end. Intramusical objectives have come to correspond to an aesthetic of autonomy, extra-musical objectives to an aesthetic of heteronomy (Varkøy, 2001). The sticking point has been the normative aesthetics' perception of musical work as 'uninteresting'; nothing external should influence the artistic process, nor should the work be downgraded to being a means for extra-musical ends (Sundin, 2003). The educational consequences of a strict autonomical approach - in which music only exists for its own sake - would be an indifference to human considerations. The opposite - a strict heteronomical approach would render music and instrumental lessons irrelevant, since objectives such as creating or reinforcing self-esteem could just as well be achieved by other means (Varkøy, 2001).

Parental views on this relationship are ostensibly more straightforward. They seldom identify a dichotomy, and consistently refer to intra-musical and extra-musical objectives as complementing one another. That a dichotomy is altogether too simplified an explanatory device is something scholars have also argued. Ruud (1996) suggests that it is precisely in its shifts and stress points that the character of music as a subject is to be found. When teaching music, it comes down to the issue of music's worth to people, since teaching leads its pupils both to music and through music.

To conclude, the ideological difficulty for Municipal Schools of Arts (MSAs) rests upon a democratic view of schools, that is, a school open to one and all. The ability 
and determination to stay flexible may indeed be found at all levels, but the rhetorical question remains of whether it is possible to be an establishment simultaneously dedicated to entertainment and education.

The MSAs enjoy great ideological freedom, as decisions on the schools' mission and activities are made on a local level. In this freedom lies the heart of the problem. It gives the schools enviable flexibility and considerable opportunities, but the same time it threatens their continued existence: schools design their operations from local, specific needs, and establish their own goals and traditions, beyond a doubt; yet at the same time, it is possible to view their activities as dispensable, as 'icing on the cake'. Freedom provides both wider and individual grounds for the schools' existence. The starting-point for their teaching methods can be music itself, tradition, or a dialogue involving children and parents concerning their expectations. Formulating music educational objectives requires an open and alive discussion in different contexts. Indeed, the starting-point for instrumental lessons specifically, as well as music education in general, ought to be a moot point for music educators and music education researchers the world over.

\section{References}

BIESTA, G. J. J. (1999) 'Postmodernism, neopragmatism och utbildning: Återkomsten för det politiska', in C. A. Säfström \& L. Östman (Ed.), Textanalys (pp. 95-113). Lund: Studentlitteratur.

CALISSENDORFF, M. (2005) 'Om man inte vill spela - då blir det jättesvårt'. Örebro: Universitetsbiblioteket. COOK, N. (1998) A very short introduction. Oxford: Oxford University Press.

DANERMARK, B; EKSTRÖM, M., JAKOBSEN, L. \& KARLSSON, J. CH. (2003) Att förklara samhället (2nd ed.). Lund: Studentlitteratur.

EDSTRÖM, O. (1996) Göteborgs rika musikliv: En översikt mellan världskrigen. Göteborg: Musikvetenskapliga avdelningen, Musikhögskolan, Göteborgs universitet.

EDSTRÖM, O. (2002) En annan berättelse om den västerländska musikhistorien och det estetiska projektet. Göteborg: Institutionen för musik- och filmvetenskap, Göteborgs universitet.

FORNÄS, J. (2004) Moderna människor: Folkhemmet och jazzen. Stockholm: Norstedts förlag.

GADAMER, H.-G. (1997 [1960]) Sanning och metod i urval [Wahrheit und Methode]. (Translated by Melberg A.). Göteborg: Daidalos AB.

GEORGII-HEMMING, E. (2005) Berättelsen under deras fötter: Fem musiklärares livshistorier. [The Story Beneath Their Feet. Five music teachers' life histories] Örebro: Örebro Studies in Music Education 1. Full text accessible on http://urn.kb.se/resolve?urn=urn:nbn:se:oru:diva-109

GEORGII-HEMMING, E. (2006) 'Music as experience. Inside and outside school', Research Alliance of Institutions for Music Education: Proceedings of the Eight International Symposium held at Schaeffergarden, Copenhagen September 29-October 1, 2005. Göteborg: ArtMonitor, Göteborgs universitet.

GLASER, B. G. \& STRAUSS, A. L. (1967) The Discovery of Grounded Theory: Strategies for Qualitative Research. New York: Aldine Publishing Company.

GLASER, B. G. (1978) Theoretical Sensitivity: Advances in the Methodology of Grounded Theory. Mill Valley, CA: Sociology Press.

GLASER, B. G. (1992) Basics of Grounded Theory Analysis. Mill Valley, CA: Sociology Press.

GLASER, B. G. (2001) The Grounded Theory Perspective: Conceptualization Contrasted with Description. Mill Valley, CA: Sociology Press. 
GRANEHEIM, L. (1994) Från musikskola till kulturskola: 'Den kommunla musikskolans uppgång och fall'...eller?. Stockholm: Centrum för musikpedagogisk forskning, Kungliga musikhögskolan i Stockholm.

GUSTAVSSON, B. (1996). Bildning i vår tid: Om bildningens möjligheter och villkor i det moderna samhället. Stockholm: Wahlström \& Widstrand.

HAMM, C. (1995) Putting Popular Music in its Place. Cambridge: Cambridge University Press.

HANKEN, I. M. \& JOHANSEN, G. (1998) Musikkundervisningens didaktikk. Oslo: Cappelen Akademisk Forlag.

HALL, S. (2007 [1993]). 'Encoding, decoding', in S. During (Ed.), The Cultural Studies Reader (pp. 477-487). London: Routledge.

JORGENSEN, E. R. (1997) In Search of Music Education. Urbana: University of Illinois Press.

JORGENSEN, E. R. (2006) 'Toward a social theory of musical identities', in B. Stålhammar (Ed.), Music and Human Beings: Music and Identity (pp. 27-44). Örebro: Universitetsbiblioteket.

KVALE, S. (1997) Den kvalitativa forskningsintervjun. Lund: Studentlitteratur.

LIEDMAN, S.-E. (1997) I skuggan av framtiden: Modernitetens idéhistoria. Stockholm: Albert Bonnier Förlag $A B$.

LYOTARD, J.-F. (1984 [1979]) The Postmodern Condition: A Report on Knowledge. Minneapolis: University of Minnesota Press.

NIELSEN, F. V. (1998) Almen musikdidaktik (2nd ed.). Copenhagen: Akademisk Forlag.

PERSSON, T. (2001) Den kommunala musikskolans framväxt och turbulenta 90—tal: En studie av schools of musicna i Mörbylånga, Tranås, Kiruna och Borås. Göteborg: Institutionen för musikvetenskap, Göteborgs universitet.

REIMER, B. (2003) A Philosophy of Music Education: Advancing the Vision (3rd ed.). Upper Saddle River, New Jersey: Prentice Hall.

RUUD, E. (1996) Musikk og verdier. Oslo: Universitetsforlaget AS.

SERNHEDE, O. (2006). 'Skolan och populärkulturen', in U. P. Lundgren (Ed.), Uttryck, intryck, avtryck: Lärande, estetiska uttrycksformer och forskning (pp. 11-18). Stockholm: Vetenskapsrådet.

SKOLVERKET. (2006) Barn, elever, personal och utbildningsresultat. Kommunal nivå. Jämförelsetal om förskoleverksamhet, skolbarnomsorg, skola och vuxenutbildning. Del 1. Rapport 276. Stockholm: Skolverket.

STENBÄCK, H. \& BOUIJ, C. (2006). 'Principals of municipal music/culture schools in Sweden: transforming their tasks', in R. R. Rideout (Ed.), Sociology of music education, Symposium IV: Proceedings from the music education symposium at the University of Massachusetts, Amherst.

STÅLHAMMAR, B. (1995) Samspel: Grundskola - Musikskola i samverkan: En studie av den pedagogiska och musikaliska interaktionen $i$ en klassrumssituation. Göteborg: Musikvetenskapliga avdelningen, Musikhögskolan, Göteborgs universitet.

STÅLHAMMAR, B. (1999) Grounded Theory och musikpedagogik: Teorigenerering med empiri som grund. Skriftserie Forskning. Örebro: Musikhögskolan, Örebro universitet.

STÅLHAMMAR, B. (2004) Musiken - deras liv: Några svenska och engelska ungdomars musikerfarenheter och musiksyn. Örebro: Universitetsbiblioteket.

STRAUSS, A. L. (1987) Qualitative Analysis for Social Scientists. Cambridge: Cambridge University Press.

STRAUSS, A. L. \& CORBIN, J. (1990) Basics of Qualitative Research: Grounded Theory Procedures and Techniques. Newbury Park, CA: Sage Publications.

SUNDIN, B. (2003) Estetik och pedagogik i dynamisk balans?. Stockholm: Mareld.

SVENSKA KOMMUNFÖRBUNDET (1976) Den kommunala musikskolan. Stockholm: Svenska Kommunförbundet.

SVENSKA KOMMUNFÖRBUNDET (1984) Den kommunala musikskolan: en resurs i kulturlivet. Stockholm: Svenska Kommunförbundet/Balder AB. 
SVERIGES MUSIK- OCH KULTURSKOLERÅD (2002) Musikalisk mångfald: En undersökning av ungdomars musicerande. Stockholm: Sveriges Musik- och Kulturskoleråd.

SVERIGES MUSIK- OCH KULTURSKOLERÅD (2006) Resultat av Musik- och Kulturskolerapporten 2006. Stockholm: Sveriges Musik- och Kulturskoleråd.

VARKØY, Ø. (1996[1993]) Varför musik? En musikpedagogisk idéhistoria [Hvorfor musikk? - en musikkpedagogisk idéhistorie]. (Translated by Ronny Lindeborg). Hässelby: Runa Förlag AB.

VARKØY, Ø. (2001). Musikk for alt (og alle): Om musikksyn i norsk grunnskole. Oslo: Norges Musikkhøgskole.

WOODFORD, P. G. (2005) Democracy and Music Education: Liberalism, Ethics and the Politics of Practice. Bloomington/Indianapolis: Indiana University Press.

\section{CAmbridge JDURALS}

